\title{
MANAGING THE LAGOS MEGACITY AND ITS GEOSPATIAL IMPERATIVE
}

\author{
S. O. Dekolo ${ }^{\mathrm{a}, *}$, A. O. Oduwaye ${ }^{\mathrm{b}}$ \\ ${ }^{\text {a }}$ Dept. of Urban and Regional Planning, Lagos State Polytechnic, Ikorodu, Lagos Nigeria - sam.dekolo@gmail.com \\ ${ }^{\mathrm{b}}$ Professor of Urban and Regional Planning, Dept. of Urban and Regional Planning, University of Lagos, Akoka, \\ Lagos Nigeria-leodwa@yahoo.com
}

KEY WORDS: Geospatial Data Infrastructure, Spatial Data Infrastructure, Geographic Information Systems, Urban Management, Megacity, Local Government, State Government, Sustainable Development

\begin{abstract}
:
Lagos has assumed the Megacity status and it is projected to have its population doubled in the first quarter of this century. The Megacity has extended beyond the administrative boundary of the state, which is also one of the fastest growing urban agglomerations in the world. Information is the most vital component of urban management; however, a survey of the spatial data infrastructure of the city proves it derisory or out-of-date, thereby creating a void between urban development and its management. This has led to a sporadic growth of slums and unplanned settlements which now accounts for over $60 \%$ of the city. To avoid an impasse, it is necessary to review the level of geospatial technologies used at the local level and recommend formidable means of integration in the decision making process. This paper examines the level of geospatial technologies the 20 local governments of Lagos State and within the Megacity region and suggests success factors.
\end{abstract}

\section{INTRODUCTION}

\subsection{Urban Management and the Geospatial Imperative}

Urban management as an activity attempts to mobilize diverse resources to work in co-operative manner in the field of planning, programming, budgeting for the development, operation and maintenance of urban areas in order to achieve the developmental objectives (Davidson, 1988). The most important issues in urban management as noted by Shalaby et al (1996) are obtaining knowledge of the location of resources, land availability and infrastructure requirement and developing integrated planning strategies to enable the channelling of resources to deal with such requirements.

Geospatial technologies provide useful tools for incorporating socioeconomic, environmental and sustainability considerations into decision-making. According to Batty (1991), these technologies can act as a bridge between theory of planning and its practice because, it affects what we plan, how we plan, who plans, and in a wide context why we plan. The use of spatial models are complementary tools in assessing the impact and effects of these emerging urban forms as well as policies, decisions, planning strategies needed in the development process and an understanding of the process.

The steady growth in the geospatial technologies due to the miniaturization of computers has removed associated technophobia and its ensured affordability. This has not only impacted the land use and socioeconomic activities within the city, but the planners' intelligent response to these changes. While planners have been empowered by technology to predict possible changes in urban structure given certain variables by modelling techniques, internet and network-based geospatial systems has made public participation and data transfer easier, also reducing planning time.
Managing cities is a complex planning task requiring multidimensional urban information (spatial, social, economic, etc.); the complexity has led to the rapid development of spatial technologies and new information and communication technologies (ICT) concepts like Expert Systems, 3D Visualization, “e-Planning” systems, Building Data Integration Systems (BDIS), Urban Decision Room, n-Dimensional Models, Public Participatory GIS (PPGIS), Spatial Planning, Smart City Planning, etc (See Wang et al, 2007).

In spite of the immense potentials of automated technologies in urban planning and management, the benefits remain unlocked in developing countries, due to poor adaptation and implementation. Furthermore, attempts are currently being made to implement geospatial technologies for planning and managing the Lagos Megacity, but will this be sustainable? This paper reviews the evolution and applications of geospatial technologies in urban planning and management in Lagos; it also reviews the past and assesses the present level of applications of geospatial data infrastructures in the Lagos Megacity and outlines a recipe for sustainable implementation.

\subsection{Global Urbanization Trend and Urban Management Problem}

The year 2008 marked the Dawn of the Urban Millennium; a silent but salient milestone in human history, in which half of humanity, about 3.3 billion now live in urban areas This figure is expected to increase to 4.9 billion by 2030 with majority of the new urbanites (about 80 percent) living in developing countries of Africa and Asia (UNFPA, 2007). However, the continuous gargantuan urbanization being witnessed in these regions has global implications on economic, social and environmental sustainability.

Urbanization has been defined as the process of transition from rural to urban society, which may reflect an increased

*Corresponding author. 
proportion of the population living urban settlements. The level of urbanization is the percentage of the total population living in towns and cities, while the rate of urbanization is the rate at which it grows (UNFPA, 2007). The continuous growth in urban areas has led to the formation of large urban agglomerations with a population of 10 million or more known as megacities. Nineteen (19) megacities have been identified in the world and it is expected to be 27 by 2020 (FIG, 2010).

\begin{tabular}{|c|c|c|c|c|}
\hline \multicolumn{5}{|c|}{ World Megacities } \\
\hline & \multirow[b]{2}{*}{ CITY } & \multicolumn{2}{|c|}{$\begin{array}{l}\text { POPULATION } \\
\text { (millions) }\end{array}$} & $\begin{array}{l}\text { Urban } \\
\text { Living }\end{array}$ \\
\hline & & 2000 & 2015 & \\
\hline 1 & Tokyo, Japan & 27.9 & 28.7 & \\
\hline 2 & Bombay, India & 18.1 & 27.4 & \\
\hline 3 & São Paulo, Brazil & 17.8 & 20.8 & \\
\hline 4 & Shanghai, China & 17.2 & 23.4 & \\
\hline 5 & New York, United States & 16.6 & 17.6 & \\
\hline 6 & Mexico City, Mexico & 16.4 & 18.8 & \\
\hline 7 & Beijing, China & 14.2 & 19.4 & \\
\hline 8 & Jakarta, Indonesia & 14.1 & 21.2 & \\
\hline 9 & Lagos, Nigeria & 13.5 & 24.4 & \\
\hline 10 & Los Angeles, United States & 13.1 & 14.3 & \\
\hline 11 & Calcutta, India & 12.7 & 17.6 & \\
\hline 12 & Tianjin, China & 12.4 & 17.0 & \\
\hline 13 & Seoul, Korea, Rep. & 12.3 & 13.1 & \\
\hline 14 & Karachi, Pakistan & 12.1 & 20.6 & \\
\hline 15 & Delhi, India & 11.7 & 17.6 & \\
\hline 16 & Buenos Aires, Argentina & 11.4 & 12.4 & \\
\hline 17 & Metro Manila, Philippines & 10.8 & 14.7 & \\
\hline 18 & Cairo, Egypt & 10.7 & 14.5 & \\
\hline 19 & Osaka, Japan & 10.6 & 10.6 & \\
\hline 20 & Rio de Janeiro, Brazil & 10.2 & 11.6 & \\
\hline 21 & Dhaka, Bangladesh & 10.2 & 19.0 & \\
\hline 22 & Paris, France & 9.6 & 9.6 & \\
\hline 23 & Istanbul, Turkey & 9.3 & 12.3 & \\
\hline 24 & Moscow, Russian Fed. & 9.3 & n.a. & \\
\hline 25 & Lima, Peru & 8.4 & 10.5 & \\
\hline 26 & Teheran, Iran & 7.3 & 10.2 & \\
\hline 27 & Bangkok, Thailand & 7.3 & 10.6 & \\
\hline 28 & Hyderabad, India & 6.7 & 10.7 & \\
\hline
\end{tabular}

Table 1. World Megacities

(Source: United Nations (U.N.) Population Division, World Urbanization Prospects, 1995

Though megacities are engines of economic growth, they have also been saddled by environmental, economic and social burdens. These burdens include growth of slums and informal settlements, unsustainable land use, commuting and traffic problem, climate change arising from energy consumption and greenhouse gases, poverty, urban violence, lack of infrastructure, poor sanitation and food insecurity etc. Furthermore, the table 1 below is the result of a research survey carried by the FIG Commission 3 to determine city administration problems in seven (7) leading cities of the world: Hong Kong, Tokyo, Seoul, Istanbul, London, New York and Lagos. The study was carried out by questionnaires (Q) and person visit (V) and interview.

\begin{tabular}{|c|c|c|c|c|c|c|c|}
\hline Problems & 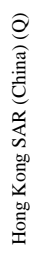 & 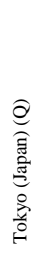 & 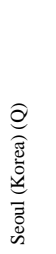 & 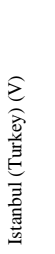 & 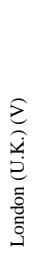 & 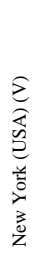 & 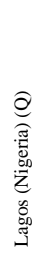 \\
\hline $\begin{array}{l}\text { Informal } \\
\text { settlements }\end{array}$ & 0 & 1 & 0 & 1 & 0 & 0 & 3 \\
\hline $\begin{array}{l}\text { Traffic } \\
\text { management }\end{array}$ & 2 & 1 & 1 & 1 & 1 & 0 & 3 \\
\hline Natural hazards & 0 & 1 & 1 & 1 & 1 & 1 & 3 \\
\hline $\begin{array}{l}\text { Unclear } \\
\text { responsibilities } \\
\text { and mandates }\end{array}$ & 0 & 0 & 0 & 0 & 0 & 0 & 3 \\
\hline $\begin{array}{l}\text { Uncoordinated } \\
\text { planning }\end{array}$ & 0 & 0 & - & 0 & 0 & 0 & 3 \\
\hline $\begin{array}{l}\text { Water } \\
\text { management }\end{array}$ & 2 & 1 & 0 & 1 & 0 & 0 & 3 \\
\hline $\begin{array}{l}\text { Provision of } \\
\text { continuous } \\
\text { electrical power }\end{array}$ & 0 & 1 & 0 & 0 & 0 & 0 & 3 \\
\hline $\begin{array}{ll}\begin{array}{l}\text { Visual } \\
\text { and } \\
\text { disposal }\end{array} & \begin{array}{c}\text { pollution } \\
\text { garbage }\end{array} \\
\end{array}$ & 2 & 1 & 0 & 0 & 0 & 1 & 3 \\
\hline $\begin{array}{l}\text { Air and water } \\
\text { pollution control }\end{array}$ & 2 & 1 & 1 & 0 & 1 & 1 & 3 \\
\hline $\begin{array}{l}\text { Population } \\
\text { growth }\end{array}$ & - & - & - & 1 & 1 & - & - \\
\hline $\begin{array}{l}* \text { Weight Score } \\
-\quad=(\text { No Info.) } \\
\mathbf{N} \quad=(\text { None })=0 \\
\mathbf{Y} \quad=(\text { Low })=1 \\
\text { Y/Med }=(\text { Med) }=2 \\
\text { Y/High }=(\text { High })=3\end{array}$ & $\begin{array}{c}29.6 \\
\%\end{array}$ & $\begin{array}{c}25.9 \\
\%\end{array}$ & $\begin{array}{c}12.5 \\
\%\end{array}$ & $\begin{array}{c}16.7 \\
\%\end{array}$ & $\begin{array}{c}13.3 \\
\%\end{array}$ & $\begin{array}{c}11.1 \\
\%\end{array}$ & $\begin{array}{c}100 \\
\%\end{array}$ \\
\hline $\begin{array}{l}\text { Ranking } \\
\text { (magnitude } \\
\text { problems) }\end{array}$ & 2 & 3 & 6 & 4 & 5 & 7 & 1 \\
\hline
\end{tabular}

Table 2. City Administration Problems in Selected Megacities (Source: Adapted from the Research Study by FIG Commission 2010)

A cursory look at table 2, which was adapted for this research, New York, Seoul and London have the lowest rankings with less than 15\%; followed by Istanbul, Tokyo and Hong Kong. The magnitude of problems is highest in Lagos owing to the fact that there is still uncoordinated planning and lack of spatial planning strategies, which have been considerably tackled in other cities through availability of Spatial Data Infrastructure.

\subsection{Lagos Megacity: The Study Area}

Lagos is the commercial capital of Nigeria and spatially the smallest state in the country an area approximately 3,577 sq. $\mathrm{km}$, out of which $39 \%$ are wetlands. However, it has the most populous city in sub-Saharan Africa, with a population of over 12 million people. Furthermore, recent studies by United Nations on World Urbanization Prospects, ranked Lagos $9^{\text {th }}$ among the 28 current and prospective megacities in the world with a standard of living score of $19 \%$. It is expected to accommodate about 24.4 million people that in 2015 (barely four years away) acquiring the status of the $3^{\text {rd }}$ largest megacity in the world trailing behind Japans 28.7 million and Bombay's 27.4 million (Redevelopment of Lagos Megacity Region Report, 2006; UNFPA, 2007). The Megacity has extended beyond the administrative boundary of the state, which is also one of the fastest growing urban agglomerations in the world. 
However, as shown in tables 1 and 2 above, the city is grappling with series of problems like congestion, pollution traffic jam, slums, housing shortage, general decay, social vices, and degradation as result of overpopulation.

In order to meet up with the challenges of managing this fast growing megacity, a presidential committee on the Redevelopment of Lagos Megacity Region was inaugurated in December 2005 with a mandate was to transform Lagos into a world class city before the end of 2015 under the chairmanship of Prof. Akin Mabogunje, which submitted its final report in April 2006. The committee recognized the Megacity region as a continuous built up area spanning over 153,540 hectares of land comprising virtually all the Local Government Areas of Lagos State and four in Ogun State i.e., Shagamu, Owode, Ifo and Ado-Odo/Otta (Redevelopment of Lagos Megacity Region Report, 2006).

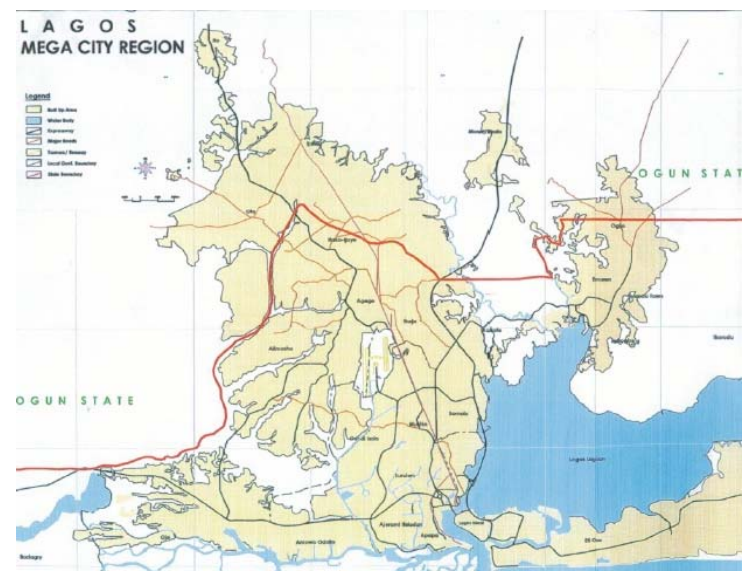

Figure 1: The Lagos Megacity Region (Source: Redevelopment of Megacity Region Report, 2006)

The committee noted that "planning activities within the megacity region, however, requires the development of an adequate cadastral database depending on availability of satellite imageries and the capacities to digitalize them along lines already initiated by the Property Identification Exercise (PIE) of Lagos State". It also identified sources of possibly acquiring the imageries as National Space Research and development Agency (NARSDA) and National Population Commission. The committee further stresses the need for developing an appropriate Geographic Information Systems for the megacity with the neighbourhoods in wards as the basic unit of data storage (Redevelopment of Megacity Region Report, 2006).

\subsection{Theoretical and Conceptual Framework Geospatial Data Infrastructures (GDI) in Urban Management}

Spatial information has become indispensable for urban planning and management. The management and planning of urban space requires spatially accurate and timely information on land use and changing pattern. Adequate monitoring provides the planners and decision-makers with required information about the current state of development and the nature of changes that have occurred (Gaduo \& Taha, 2004).

Geospatial technologies like Geographical Information Systems (GIS) and remote sensing provides essential tools for urban management at regional, districts and local planning levels and improve the capacity of city government and planners' decision-making process. In most developing countries, geospatial information have been developed, used and maintained by some government and private agency separately, while efforts have been agency-focused, uncoordinated and duplicated. However, having a framework for integration and sharing of geospatial data can help improve the decisionmaking process and management of resources to produce overall benefits in megacity and state (EIS-AFRICA, 2002).

The concept of Geospatial Data Infrastructure (GDI) also known as Spatial Data Infrastructure (SDI) has been adopted by many megacities in developed countries to help facilitate cooperative production, use and sharing of geospatial data. Regional and global initiatives are taking place as well. GDI usually comprises of data itself, standards, policies, technologies, and procedures for different agencies and organization to cooperatively produce, use and share geographical information.

GDI or SDI is defined as the technology, policies, standards, and institutional arrangements necessary to acquire, process, store, distribute and improve the utilization of geospatial data from different sources and for a wide range of potential users (Woldai, 2003). It is an initiative intended to create an environment that enables a wide variety of users to access and retrieve complete and consistent data sets in easy and secure way. As a tool, it provides an environment in which all stakeholders can cooperate with each other and utilize technology in a cost effective way to better achieve the objectives at the appropriate political and administrative level, i.e. local, national, regional or global level (Rajabifard et al, 2000).

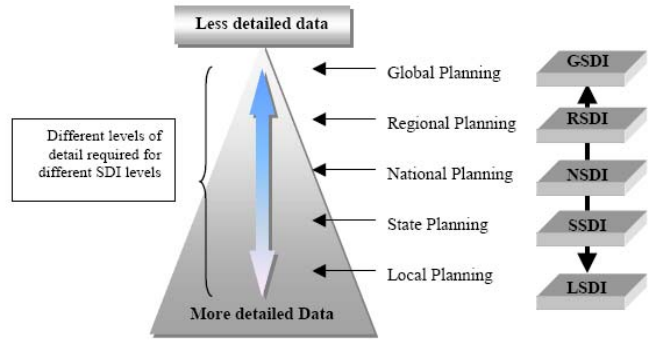

Figure 2: Relationship between Data and Different forms of SDI (Rajabifard et al, 1999)

GDI/SDI could be viewed from two hierarchical perspectives as illustrated in Figure $3 \mathrm{~A}$ and 3B (See Rajabifard, Chan \& Williamson, 1999). The umbrella view in which a higher level SDI encompasses all the components of a lower level SDI, e.g. at the global level, it could encompass the policies, technologies, standards and human resources necessary for the effective collection, management, access, delivery and utilization of geospatial data in a global community (Rajabifard et al, 2000). At the national level for example, the National Geospatial Data Infrastructure (NGDI) encompasses all the components of the 36 states' SDIs. The national SDI has been described as an umbrella of policies, standards, and procedure under which organizations and technologies interact to foster more efficient use, management, and production of geospatial data. This suggests that, ideally at a national level, there is in place the necessary institutional framework, the technical standards, the access network and the people necessary to 
support sharing of spatial fundamental datasets kept at the lower levels, such as the states and local government levels.

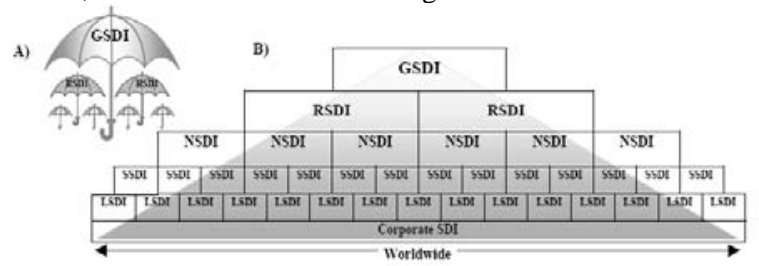

Figure 3 A) The Umbrella View of SDI B) The Building Block View of SDI (Rajabifard et al, 2000)

The second, which is the building block view, in which SDIs at a lower level, say the local government levels (e.g. District Planning Offices) serve as the supporting building blocks to provide spatial data needed by SDIs at a higher level in the hierarchy such as the state, national or regional levels. This facilitates data sharing, transfer and partnerships, while reducing the overall cost of data collection. Based on these two views, the SDI hierarchy creates an environment in which decision-makers working at any level can draw on data from other levels, depending on the themes, scales, currency and coverage of the data needed (Rajabifard, Chan \& Williamson, 1999).

Several scholarly articles have been written on the subject of GDI and SDI at global, regional, national and citywide scales (See Crompvoets \& Bregt, 2003; Boos \& Muller, 2009; Makanga \& Smit, 2008; Makanga \& Smit, 2010) however, little has been done on assessing departmental and local government GDI which form the base or foundation for other GDIs. This is one of the salient gaps this research tends to fill.

\subsection{Hindsight to GDI Applications in Lagos State}

Lagos State with the help from the World Bank attempted to implement a GIS for the first time in 1996 under the Ministry of Lands and Housing known as Land Related Information System (LRIS), this led to the establishment of the Land Information System Support Unit (LISSU). The first phase which was a pilot scheme was completed in 1997. The product of the pilot was detail GIS thematic maps for 40 Square $\mathrm{km}$ of the metropolitan area; for the rest of the city, small-scale mapping and orthophotos. The LRIS system was to provide a geographical database and documentation of all land transactions in the state. This application was aimed at revenue generation and effective collection of land based charges, but it was short-lived (Dekolo, 2001; Dekolo and Oduwaye, 2005).

Another effort towards developing its GDI is the development of Lagos State Planning Information Centre (LASPIC), a GIS centre created for urban and regional planning purpose under the Ministry of Physical Planning and Urban Development (MPPUD). The project was to be a web-based GIS, having a central server at LASPIC and its database can be accessed through wireless Internet and Intranet network from the MPPUD, LSURPB, all the District Offices (DO) and Local Planning Offices (LPO). The centre was established for archiving and retrieval of information for planning, managing and monitoring physical development in the state. The project aimed at developing a document archival system and kiosk based planning solution that will safe guard records and reduces volumes of files. This will allow all planning applications in the state to be submitted and transferred online from all the LPOs and DOs in digital format to the central database and stored.
This will strengthen the development control monitoring system and further manage urban growth, since it will also be linked to other thematic data like land use, cadastral maps, etc (Dekolo and Oduwaye, 2005).

\section{METHODS, RESULTS AND DISCUSSION}

\subsection{Research Method}

In order to assess the level of geospatial technologies application in agencies responsible for managing the Lagos Megacity, 30 questionnaires were sent out to all District Planning Offices within 16 local governments in the megacity, 6 Regional Development Agencies and 8 other Lagos State agencies as follows: Lagos State Physical Planning and Development Authority(LSPPDA), Lagos State Urban Renewal Authority (LASURA), New Towns Development Authority (NTDA), Lagos State Ministry of Transport (MOT), Ministry of Physical Planning and Urban Development (MPPUD), Lagos State Planning Information Centre (LASPIC), Ministry of Lands (Surveyor General's Office). Questions include the use of GIS technology, GIS software used, availability of funds, if there is link with the national SDI (NSDI) and basic problems faced in the implementation of Geospatial Data Infrastructure. 20 questionnaires were returned and were grouped into State Planning Agencies (8) and Local Government Planning Agencies (12).

The result of the survey shows that only 30\% of the District planning offices have adopted GIS technology and make use of ArcGIS software; only the LASPIC Centre make use of other packages like ILWIS, MAPINFO and other software. Though the entire respondents understood the concept of GDI and SDI vaguely, all the agencies do not have a relationship with the NSDI except LASPIC. On problems militating against effective use and applications of GDI in the Megacity, all the agencies are currently faced with problems in developing core data, metadata and maintenance of data, political and legal constraints.

\subsection{Current GDI Initiative in Lagos State}

Though the result of the survey looks gloomy, it is worthy to note that the Lagos State Government on March $7^{\text {th }} 2011$ launched its N3bn Digital Mapping/Geographic Information System (GIS) to solve these problems. The project is acclaimed to be the most comprehensive GIS in the country providing a new information highway for the government, private sector and individuals to obtain spatial information. The whole state fully mapped on aerial photos at a scale of 1:4000 while digital maps are now at a scale of $1 / 500$ for Lagos metropolis and 1/1000 for rural areas and orthophotos for the whole state is at $1 / 2000$ and DTM. The data infrastructure will be integrated with the Electronic Data Management System (EDMS) for accurate information about land ownership, use etc (Hamzat, 2009; Lagos State Government, 2011).

The project known as LAGIS spread across the six broad technical modules; acquisition of digital aerial imageries and establishment of geodetic control; establishment of geoid and active Global Positioning System and reference station with Continuous Operating Reference Station; digital mapping, Digital Terrain Model and orthophoto maps; enterprise GIS, bathymetry chart; and provision of information and 
communication technology infrastructure, as well as education and training (Hamzat, 2009).

The objectives of the project include ensuring effective use and application of geospatial information in providing sustainable planning and development of the ever-growing Megacity. It will also provide effective inventory and monitoring of the environment; serve as additional platform for the building of information database, improved health care, educational and sports facilities planning, development and delivery. Finally, it will provide the bedrock for e-government, communication among ministries, department and agencies, while enhancing economic empowerment and infrastructural development. Another important component of the project is called The Lagos Navigation System, which will help commuters find streets and locations around our State from their computers or in their vehicles. This will also be applied in the location of utilities for power, water supply, waste management facilities and so much more (Lagos State Government, 2011).

\subsection{Path to Sustainable Geospatial Implementation}

The early shout of Uhuru by the Lagos State Government at the launch of its GIS project may be short-lived like previous projects except precautionary steps are taken to make it sustainable. Though the project surpassed previous ones in its planning and implementation by making use of local consultants, other success factors that are critical to its sustainability includes: maintaining a clear focus and empowering project champions that will drive the project on; improving the state of infrastructure (especially electricity), which presently is a minus; educational issues and training of staff should be looked at; continuous executive commitment even when there is a change of administration; making it locally relevant and adopting a socio-technical approach; the need to ensure an ongoing strategic planning and continuous reappraisal (See Oduwaye \& Dekolo,2005; Dekolo \& Oduwaye, 2005; Somers 2000, Lombard 1999, Gallaher 1999, Davis 1999, Somers 1999, Kevany 1998, Somers 1996, Shalaby et al 1996, Somers 1994, Mahoney 1991 and Masser 1989).

\subsubsection{Clear Focus and Project Champion}

Gallaher (1999) had identified one of the three major killer of GIS is losing focus or not remembering the reason for such investment. A guiding principle for the LAGIS project must be keeping a clear cut vision throughout the post implementation period. This can be achieved though the role of a project champion i.e. someone single-mindedly committed to the cause of the project (Mahoney 1991).

\subsubsection{Technological and Organizational Environment}

The technological and organizational environment is crucial to successful implementation of any GIS (see Somers 1996). The organizational environment of any project has its own peculiar politics, constraints and opportunities; this should be a major consideration if the LAGIS will be sustainable.

\subsubsection{Organizational and Staffing Issues}

The introduction of GIS in any planning organizations will have a very significant effect on its activities, therefore the strategy should consider the structure of the agency to adopt the GIS, and the skills of staff to manage and operate the systems (see Somers 1994). One of the hidden risks for a GIS is inability for organization to deal with their own organizational and political problems, since appointment of consultants and staffs are still based on some local politics rather than for the benefit of such projects success may be out of reach.

\subsubsection{Educational and Training Issues}

This involves training the current staff of the Ministry of Physical Planning and Urban Development, LSPPDA, LASURA, LASPIC etc., on necessary skills to be able to work in a GIS environment. It also involves setting a standard for recruitment in which new staff from technical level upward must have attended a minimum training in GIS.

The key issue for success in the LAGIS project lies in the people responsible for managing; implementing and using the systems. Without properly trained personnel with vision and commitment to the project, little will be achieved (see Somers 1994; Shalaby et al, 1996).

\subsubsection{Executive commitment}

Except the LAGIS project receives adequate support now and from the decision makers and politicians i.e. political will, such project will not work. To get executive commitment Davis (1999) identified some keys: Managing expectation of the executives and make them realize the benefits of the investment at short term bases i.e. at every stage of the implementation plan; Making decision makers to be involved in planning and integrating them in the project; Educating them and creating more awareness.

\subsubsection{Socio-Technical Approach}

Most GIS projects are techno-centric and once the local endusers are left without the technical capability to operate or manage the project, it becomes a clog in the wheel. It has been established that technology can only operate successfully within some social or organizational context. GIS technology is bound to shape planning organizations, however, organization should shape the technology; therefore end users should be involved in developing customized GIS applications and other aspect of the implementation process at the various department and local government levels.

\subsubsection{Geographic Information Policy and Standards}

To implement a GIS for urban and regional planning and management legislation is often required. Presently, there is a Lagos State GIS policy, which is modelled after the NGDI policy; however, there is need for implementing these standards in various local government level and government departments. The policy is will ensure institutional support even if there is a change in the political or economic climate, hence making it sustainable.

\subsubsection{Ongoing Strategic Planning and Continuous Re- appraisal}

Planning is the most important phase in any GIS implementation. However, many try to overlook or create short cuts due to some political or administrative pressure (Somers 1996). More so many problems that arise at various stages in the GIS development and operation can be traced back to inadequacies in the strategic planning process, lack of follow through and failure to oversee the plan (Somers 2000). In previous GIS projects (e.g. LISSU Project), there were good plans but due to lack of follow up the plan has not been actualized. Strategic planning is crucial to any GIS success but beyond the initial plan it must be on-going processes repeatedly perform throughout the project's life cycle. There is need for a continuous re-appraisal and re-evaluate its situation and 
directions at given intervals through annual reviews, full reexamination of project achievements during the implementation process (See Kevany, 1998; Somers, 2000).

\subsubsection{Communication, Data Access and availability}

Communication is vital and important to the successful implementation of a GIS. Presently, there is lack of data sharing between agencies and individuals who are custodians of data on the megacity region, which were acquired with tax payers' money. Where data is available, they are viewed as a commodity and are hoarded. Consideration should be made to give incentives for data sharing and disincentives or penalty for hoarding. Also there is need to develop a clearing house for data on the region, where metadata by different custodians can be accessed online.

\subsubsection{Appropriate Local Geospatial Data Infrastructure (LGDI) Pilot}

As part of the LAGIS and the Lagos State's GDI, there is need for designing a pilot LGDI; this is because planning data are acquired at the local and neighbourhood levels. The satellite imageries and other data collected cannot be useful without accurate baseline data at the neighbourhoods and ward levels. The authors are currently working on developing a clearinghouse for Ikorodu LGDI; this will be on a web portal very soon and data can be downloaded free of charge.

\section{Conclusion and Further Work}

The paper had presented a number of issues on theoretical and technical foundations of geospatial technologies applications in urban management; it has looked at the need for having a sustainable geospatial data infrastructure for efficient and effective management of the Lagos Megacity, owing to the fact that the region is saddled with several problems and could be seen as one of the worst and unliveable city globally.

While we agree that geospatial technology is good, it should be noted that it is people that shape technology; while institutional and socio-economic issues should not be underplayed in the current wind of change. A sustainable GIS technology in a developing country like ours will societal acceptance, which awareness and educating the society about GIS as tool for socio-economic development can play this role. Moreover, there is need for adequate education and training of urban and regional planners, who are the key managers of the cities.

As a follow-up of this paper, the authors are currently investigating the use of web portals for real time monitoring of land use change within the megacity. It is hope that this research will build a solid foundation for a sustainable future in the Lagos Megacity. Thank You.

\section{REFERENCE}

Batty, M. (1991). New Technology and Planning. Town Planning Review , 62 (3), 269-293.

Boos, S., \& Muller, H. (2009). SDI Developments in the World's Currently Existing Mega Cities. Spatial Information for Sustainable Management of Urban Areas (pp. 1-19). Germany: International Federation of Surveyors.
Crompvoets, J., \& Bregt, A. (2003). World Status of National Spatial Data Clearinghouses. URISA Journal , 15, 43-50.

Davies, J. (1999). Six Keys to Gaining Executive Commitment to GIS. In M. J. Salling (Ed.), Urban and Regional Information System Association Proceedings (pp. 566-570). Chicago: URISA.

Davis, B. E. (1996). GIS: A Visual Approach. New York: Onword Press.

Dekolo, S. O. (2001). Implementing GIS for Land Use Planning and Management in Lagos. In M. J. Salling (Ed.), URISA's 39th Annual Conference (pp. 173-182). Long Beach: Urban and Regional Information Systems Association.

Dekolo, S. O., \& Oduwaye, O. A. (2005). GIS Education and Trainning: The Missing Link? AfricaGIS 2005. Pretoria, South Africa.

FGN. (2006). Report of the Presidential Committee on Redevelopment of Lagos Megacity Region. Lagos: Federal Government of Nigeria.

FIG. (2010). Rapid Urbanization and Mega Cities: The Need for Spatial Information Management. Copenhagen: The International Federation of Surveyors (FIG).

Gadou, H. M., \& Taha, D. A. (2004). Use of New GeoInformation Technologies to the City Monitoring in Fast Growing Metropolises an Megacities. Sustainable Architecture and Urban Development. Cairo: Cairo University.

Gallaher, D. (1999). Three Leading Killers of GIS. In M. J. Salling (Ed.), Urban and Regional Information System Association Proceedings (pp. 585-586). Chicago: URISA.

Hamzat, K. O. (2009, April 15). Lagos State Press Briefing. Retrieved December 9, 2010, from Lagos State Government: http://www.lagosstate.gov.ng/c/portal/layout?p_l_id=PUB.1006 .35

Kevany, J. M. ( 1998). , 1998. "Managing Systems Implementation to Achieve Benefits," in . Edited by . > pp. . In M. J. Salling (Ed.), Urban and Regional Information System Association Proceedings (pp. 550-558). Charlotte, North Carolina: URISA.

Lagos State Government. (2011, March 8). Lagos State Press Breifing. Retrieved March 10, 2011, from Lagos State Government: http://www.lagosstate.gov.ng/

Lombard, M. (1999). Title Registration Strategies: Success and failures. In M. J. Salling (Ed.), Urban and Regional Information System Association Proceedings (pp. 552-560). Chicago, Illinois: URISA.

Mahoney, P. R. (1990). Does it Work and does it fit. The Association for Geographic Information Proceedings. Brighton, UK: AGI.

Makanga, P. T., \& Smit, J. (2008). A review of Spatial Data Infrastructure implementation in Africa. International conference on Free and Open Source Software for geospatial. Cape town. 
Makanga, P., \& Smit, J. (2010). A Review of the status of Spatial Data Infrastructure Implementation in Africa. The South African Computer Journal , 45.

Masser, I. (1989). Technological and Organisation Issues in the Design of Information System for Urban Management in developing countries. Sheffield: The University of Sheffield.

Oduwaye, L., \& Dekolo, S. (Eds.). (2005). GIS Applications in Urban and Regional Planning. NITP LAGOS STATE CHAPTER CPD WORKSHOP (pp. 1-22). Lagos: NITP Lagos Chapter.

Rajabifard, A., Chan, T. O., \& Williamson, !. P. (1999). The Nature of Regional Spatial Data Infrastructures. The 27th Annual Conference of AURISA (pp. 3-7). Blue Mountains: Australasian \& Regional Information Systems Association.

Rajabifard, A., Williamson, I. P., Holland, P., \& Johnstone, G. (2000). From Local to Global SDI initiatives: a pyramid of building blocks. 4th Global Spatial Data Infrastructure Conference. Cape Town, South Africa.

Shalaby, T., Ford, P., \& Whitehead, M. (1996). Frame Work for the Provision of Sustainable Technology in Developing Countries. In T. Llyod-Jones (Ed.), Computers in Urban Spatial Planning: A Guide to Research for developing world Applications (pp. 11-22). London: ODA.

Shalaby, T., Ford, P., \& Whitehead, M. (1996). The use of GIS in modeling planning information for social integration, case study,Johannesburg. South Africa. In Computers in Urban Spatial Planning: A Guide to Research for developing world Applications (pp. 23-32). London: ODA.

Somers, R. (1991, February). GIS in US Local Government. Cities , 25-32.

Somers, R. (1994). GIS Organization and Staffing. Urban and Regional Information System Association Proceedings (pp. 4152). Maine: URISA.

Somers, R. (2000). GIS Strategic planning . In M. J. Salling (Ed.), Urban and Regional Information System Association Proceedings (pp. 463-469). Orlando, Florida: URISA.

Somers, R. (1996, January ). How to Implement a GIS. Geo Info System , pp. 18-21.

UNFPA. (2007). State of the World Population 2007: Unleashing the Potential of Urban Growth. New York: United Nations Population Fund.

United Nations Population Division. (2006). World Urbanisation Prospects: The 2005 Revision. New York: United Nations.

Wang, H., Song, Y., Hamilton, A., \& Curwell, A. (2007, July 17). Urban Information Integration for Advanced e-Planning in Europe. Government Information Quarterly , 24, pp. 736-754.

Woldai, T. (2003). Overview of NGDI Concept and Components . NGDI Stakeholders and Users Workshop. Abuja, Nigeria. 
International Archives of the Photogrammetry, Remote Sensing and Spatial Information Sciences, Volume XXXVIII-4/C21 